\title{
Looking for democracy in fiduciary government. Historical notes on an unsettled relationship (ca. 1520-1650)*
}

\author{
Buscando la democracia en el gobierno fiduciario. Apuntes \\ históricos sobre una relación irresoluta (c. 1520-1650)
}

DAVID GUERRERO**

\begin{abstract}
A recent perspective on the normative foundations of public law has proposed to conceive citizen-state relationships as a "fiduciary relationship", using private-law fiduciary duties to justify legal and moral constrains on state power. Fiduciary government has also been pointed as a distinct feature of republicanism and popular sovereignty, since it places the political community as trustor and beneficiary of any administrative act. This paper reviews some early modern conceptions of government considering their explicit fiduciary justifications. It concludes with a fiduciary account of Leveller natural law, especially needed to understand (and maybe to restore) the relationship between fiduciary government and democracy.
\end{abstract}

Keywords: trust, fiduciary power, republicanism, divine right, Calvinism, Levellers

\begin{abstract}
Resumen: Una perspectiva reciente sobre los fundamentos normativos del derecho público ha propuesto concebir las relaciones entre ciudadanía y Estado como una "relación fiduciaria", usando deberes fiduciarios del ámbito iusprivado para justificar limitaciones jurídicas y morales al poder del Estado. El gobierno fiduciario también ha sido señalado como una característica distintiva del republicanismo y la soberanía popular, ya que sitúa a la comunidad política como fideicomitente y beneficiaria de cualquier acto administrativo. En este artículo se revisan algunas concepciones protomodernas del gobierno considerando sus justificaciones explícitamente fiduciarias. Concluye con una interpretación fiduciaria del iusnaturalismo leveller, especialmente necesario para entender (y puede que restaurar) la relación del gobierno fiduciario con la democracia.
\end{abstract}

Palabras clave: confianza, poder fiduciario, republicanismo, derecho divino, calvinismo, levellers

Recibido: 20/05/2020. Aceptado: 17/06/2020. Cómo citar este artículo: Guerrero, D. (2020). Looking for democracy in fiduciary government. Historical notes on an unsettled relationship (ca. 1520-1650). Daimon. Revista Internacional de Filosofía, (81), 19-34. https://doi.org/10.6018/daimon.428801

* This work was funded by the project PGC2018-094324-B-I00 (MCIU/AEI/FEDER, UE) and by the doctoral research contract FPU18/01120 (MCIU).

** PhD candidate, Department of Sociology, University of Barcelona. Email: david.guerrero@ub.edu. His doctoral project is titled "Free speech, republicanism and the political economy of communications". It aims to show, historically and conceptually, how claims to free speech within republican tradition are not merely negative (i.e. claims of non-interference) but political demands necessarily informed by normative expectations regarding a certain distribution of communication-related resources. Recent publications: Guerrero, D. (2020), "Redes sociales, algoritmos y democracia”, Revista de Estudios Políticos, 187, pp. 235-243; Guerrero, D. (2020), “"Razones para tolerar a los papistas igual que a otros'. La Iglesia Católica y el nuevo manuscrito de John Locke", Sin Permiso, 17, pp. 219-228. 


\section{Introduction}

Recent scholarship on public law and legal philosophy is attempting to restore the "fiduciary" foundations of government (Fox-Decent, 2012; Miller and Gold, 2015; Criddle et al., 2018). A fiduciary conception of political authority frames the duties of the state and its agencies as similar to those of a fiduciary agent or trustee in a private-law relationship. It serves to justify limits on political authority: against self-dealing, a duty of loyalty and care to the beneficiary party (i.e. the citizens), mechanisms of transparency and accountability, and so on. Every legitimate administrative act, the argument goes, ought to be justified in terms of the interests of the interfered individuals and may potentially be disputed by them. Unsurprisingly, the idea of fiduciary government — of a government based upon its subjects' trust - has been pointed as a distinct feature of republican tradition (Pettit, 1997, 8-9). This understanding of government "boasts a venerable pedigree in legal and political theory" (Criddle et al., 2018, 69-70). As I intend to show, part of such "venerable pedigree", though maybe amusing for present-day political philosophers, is not republican or constitutional, and much of it is arguably antidemocratic.

In formal terms, fiduciary government does not need to claim the subjects' willingness to be under state power (Fox-Decent, 2012). Its worth consists in justifying the rule of law and fundamental individual rights avoiding the potential resort to a chaotic unilateralism. Its normative reasoning can be thus independent from consent, as in the case of many private-law fiduciary institutions, e.g. guardianship: a guardian has not been necessarily chosen or given consent by her ward, but she is nevertheless liable due to her position as a fiduciary of the ward's interests. Similarly, the fiduciary duties of public institutions can be rooted merely in the interests of a non-agential political community facing the irresistible administrative power of the state. The fact that undemocratic western thought could use fiduciary language and trust-based institutions to defend unconsented political authority while undermining claims of popular agency should not surprise us - after all, private-law institutions regulating fiduciary relationships were originated due to the legal incapacity of trustors and/or beneficiaries (Lee, 2018).

We may be tempted to dismiss some of these cases as rhetorical or as a fiduciary ideological veil that hides selfish rule and despotism by proclaiming that it is the people's best interests - and this temptation may grow when fiduciary government is mixed with theology. But then, why do not we do the same with other fiduciary but also undemocratic examples considered more desirable just because they are closer to an abstract tradition of constitutionalism? Cicero and James I of England defended the fiduciary nature of public office in their own ways. If we reflect on the hypothetically unfulfilled interests of their respective beneficiaries, in what sense can we say that Cicero's fiduciary conception of government is more legitimately fiduciary (or less rhetorical) than James I's? Both proclaimed an other-regarding power, but both saw the proclaimed beneficiaries of that power - the "people" - as incapable of vindicating their interests by themselves.

Albeit its close connections with normative thought, political history and institutions are not guided only by logical implications. If we are building a normative theory inspired by historical thought, a certain historical-institutional awareness might be needed. If not, we are likely to build our ideas upon the intuitions, prejudices or preferences of others - which 
might not be compatible with ours. This is not a rejection of the entire western canon, nor I deny that a historically rooted normative principle can be abstracted beyond its contextual boundaries. It is just a call to review the premises of our sources in the light of their social context; and many cases of fiduciary government were developed with explicitly anti-democratic purposes, which may be thoughtlessly incorporated in contemporary theory. I believe it is not by chance that the two most successful and consistent theories of republicanism and fiduciary government share an explicit fear of robust popular agency (Pettit, 1997; Fox-Decent, 2012).

In this paper I aim to show how a shared fiduciary understanding of public authority can give rise to diverse political arrangements and theories. From an institutional point of view, fiduciary government is not about the mental state of trust, but about setting the foundations for a rational trust: to create trustworthy institutions. I believe this gets us closer to grasping the normative appeal of, say, today's democratic parliaments versus Calvinist lesser magistrates. It is reasonable to think that demands for a robust popular agency were an essential step to achieve institutional trustworthiness - historically and conceptually. The central hypothesis of this research is that early modern fiduciary government was a politically contested concept. Revisiting it in the light of the radical innovations carried out by the English Levellers provides conceptual trails and historical reasons to reevaluate the role of democratic republicanism in shaping up an understanding of fiduciary government appropriate for contemporary democracy.

\section{2. "God's trustees": The fiduciary foundations of theocracy}

In medieval and early modern times, when the secular notion of sovereignty as an absolute and unbounded power was still atypical, even the most arbitrary political projects had to depict themselves as commissioned by God, at the very least accountable to him. Probably the most famous assertion of a divine commission behind kingship is The Trew Law of Monarchies (1598) by James VI of Scotland, later James I of England. Kings "sit upon GOD his Throne in the earth (...) to procure the weal and flourishing of his people, (...) and to maintain concord, wealth, and civility among them (...)", like "a careful watchman, caring for them more than for himself". Kings were "countable to that great God, who placed him as his lieutenant over them" because their subjects were "committed to his charge" (1994, 64-65).

Although monarchical theocracy was not born in 17th century England, James' straightforward formulation of the divine right of kings has been seen as a typically early modern phenomenon, partially due to the Reformation and the development of strong central monarchies that needed to uphold their autonomy from the papacy at first and from Calvinist theories of resistance later on (Figgis, 1922). But highlighting the fiduciary rationale behind kingship helps us to make sense of that apparently contradictory empirical reality: divine-right monarchies that nevertheless were subject to multiple legal constrains, national customs and local checks on their power. According to Louis XVI's tutor, for instance, while the King's "power coming from on high", "they must not", however, "believe that they are owners of it, to use it as they please; rather must they use it with fear and restraint, as something which comes to them from God" (Bossuet, 1990, III, II, 4). 
Notwithstanding the factually limited powers of early modern monarchs, being the trustee of a godly commission still shapes a powerful argument against secular constraints. In making the case for a "dispensing" executive power to attend contingencies unpredictable by written laws, Sir Roger L'Estrange, a later English royalist pamphleteer, thought fit to frame such an authority as a "Fiduciary power" based upon "trust". His plea for decisionism had a clear fiduciary architecture: Principal (God) - Agent (King) - Beneficiary (People).

God's Vicegerents are Answerable to their Principal for the Care and Protection of the People Committed to their Charge; That it is Impossible for them to Acquit Themselves of their Trust, Duty, and Commission, purely by the Force of Laws of Man's Making, without some Higher Power to Resort to for Relief; (...) God has Entrusted them Beforehand; for Kings are God's Trustees, not the Peoples (L'Estrange, 1678, 1).

Ultimately, however, the normative outcome of a fiduciary power committed by God depends on who is able to know and judge the divine "trust" that rests upon the king. From an strictly secular point of view, if only the monarch can decipher the content of God's commission (i.e. if that very fiduciary agent is the only one who can check the fulfillment of his or her duties), the self-proclaimed "commission", "mandate", "trust", "vicariate" may be nothing but the ruler's perfect hoax to be held accountable by no one else except by his or her own conscience. But what if there were other individuals able to fathom the terms established by the divine trustor?

\section{Bypassing God's trustees: Promises and limitations of religious accountability}

\section{I}

James VI/I has been rightly considered the ideological pioneer of later Stuart absolutism. By affirming his divine right, however, James was also underlining that Anglican principle in international politics derived from Henry VIII's Act of Supremacy (1534) by which Parliament defined the English monarch as "Supreme Head" of the Anglican Church. With the Act and the successive Oaths of Allegiance, English monarchs stopped being accountable to God's vicar in Rome to become directly accountable to God himself.

Most of Roman Catholicism had defended papal interferences in civil matters precisely by monopolizing divine communications. But ancient imperial theocratic tendencies competed with the papacy for the privileged place as immediate trustee of God's power -Charlemagne's kingship, for instance, was conceived in the Councils of Paris and Worms (829) as a "ministerium a Deo commissum" (Gierke, 1900, 141). In order to curb God's fiduciaries, one must be capable of defining the content of God's mandates. That was the role of papal supremacy over secular powers established by the Gregorian Reform (Domènech, 1999). During the early 12th century Investiture Controversy against imperial and monarchical ambitions, the ecclesiastical party considered heretical to think that God could have appointed "duos vicarios aequales in terries" (two equal vicars on Earth). The pope, as St. Peter's heir, was the owner of both swords by the immediate 
delegation of God. Yet the papacy owned the secular sword only customarily (in habitu), but not factually (in actu). Thus, the civil magistrates - the factual holders of the secular sword - could hold their office merely as a usus inmediatus or dominium utile ${ }^{1}$, i.e. never becoming its ultimate owners (Gierke, 1900, 13-14).

Decretalists under Pope Innocent III (1198-1216) refurbished papal supremacy by claiming that St. Peter's successors wielded a "plenitudo potestatis" entrusted by God. Later, Boniface VIII's Unam sanctam (1302), stated that "if the earthly power errs it shall be judged by the spiritual, if the lesser spiritual power errs it shall be judged by the greater spiritual power, but if the supreme spiritual power errs it can be judged by God alone" (Tierney, 1982, 43). The Italian cardinal Robert Bellarmine $(2012,160)$ recovered these medieval tenets at the end of the 16 th century, reminding his contemporaries - protestant James VI/I and Gallican catholic William Barclay alike - that "sword is under sword". In the fiduciary equation that started with a trustor God and finished with a beneficiary community, "the Pontiff and the king are not two magistrates immediately below Christ" (2012, 277).

Moreover, these principles were reinforced by a certain idea of "popular sovereignty" behind any secular power, which made the civil magistrate accountable to the people's welfare (the aim of the alleged divine commission watched over by the Church). Consequently, we also find consent-based government - a commonplace in scholastic political philosophy (Skinner, 1978; Tierney, 1982, 2001) - even in the more obstinate champions of papal supremacy and Rome's absolutist power. These are the repeteadly discussed traces of "constitutionalism" that one can find in Jesuit "contractual" descriptions of secular power (e.g. Suárez, 1944a, bk. III, 4, 6-9; Bellarmine, 2012, 18-23).

All the Jesuit displays of "popular sovereignty", however, completely vanish in their account of Rome's "spiritual" or "indirect" - but still coercive - power. In his Defensio fidei catholicae (1613), a polemic tract against James I's divine right in which Suárez followed Bellarmine closely, we see that ultimately it is only God through the pope, his immediate minister on Earth, who should judge the fulfillment of a civil magistrate's fiduciary duties (Suárez, 1944b, bk. VI, 4, 16)². Suárez cleverly aligned James I with Marsilius of Padua and other "enemies of the church" (1944b, bk. III, 23, 1), since the divine right of kings as stated by the English monarchs undermined papal authority as much as older conciliarist theories did. In their own way, both heresies dismantled the pope's monopoly over the godly trust. That monopoly justified itself through a fiduciary structure: it arraigned the numerous and overlapping secular and religious jurisdictions of Europe in a certain hierarchy of downstream delegations of power, concessions and prerogatives, with the Petrine commission at the very top. Walter Ullmann could not have epitomized his "descending theme" of medieval government more to the point: "In short, power in the public sphere was a divine trust" $(2010,30)$.

1 Recall Francis Bacon's definition of the use in common law: "usus est dominium fiduciarium" (Maloy, 2008, 38).

2 There are exceptions of legitimate private action against the monarch in the Defensio: in case of self-defense against physically violent actions directed by the authority to the private individual or to the community (Suárez, 1944b, bk. VI, 4, 4-6) or in the case of a usurper (bk. VI, 4, 8). But punishment is a right of office, and therefore one may recur to it only if there is no superior jurisdiction (and there was: the spiritual power of the pope). 


\section{II}

Calvinism had to dispute this all-embracing downstream "divine trust" with a twofold objective: to legitimate the deposition of, and resistance to, non-reformed rulers while contesting Rome's "spiritual" power. Continental Calvinism appealed to "ephors", "optimates" and "tribunes" - inferior magistrates committed by God to resist (or lead the resistance) against ungodly tyrants.

In the infamous Huguenot tract Vindiciae contra tyrannos (1579) the power of kings comes from a "duplex foedus", a twofold covenant: the first between God and people (king included), which are conceived of as a debtors with a joint liability to their divine creditor (Brutus, 1994, 37-38); the second between people and king, by which magisterial authority was created for certain purposes — and "God willed that it should be done in this way, so that whatever authority and power [the kings] have, should be received from the people after Him; and that thus they would apply all their care, thought, and effort to the welfare of the people" $(1994,54)$. Therefore, the commonwealth is "entrusted to the king as its supreme and principal tutor" with the nobility acting as its "co-tutors" (1994, 159). Among the many topics and cases considered in the Vindiciae, there is one that crucially sets the relationship of its fiduciary understanding of government with democracy. What happens if not only the king, but also the secular and/or religious co-tutors fail their duty toward the people? Obedience is the answer: "people themselves turn to God in their hearts; and that it is a task for bended knees, not arms and legs" (Brutus, 1994, 170).

All three views of government reviewed hitherto - the divine right of kings, papal supremacy and Calvinist resistance theories - accepted that political power has a fiduciary nature, originally and conditionally transferred by God, mediately or immediately, to his lieutenants on Earth, in the benefit of God's people. Each group, however, justified its own political project by modifying the hierarchical order established by the divine trusteeship. They placed different institutions in the position of who had the right to decipher God's mandate: the monarch, the pope or lesser magistrates akin to the presbyter. But the very beneficiaries of the trusteeship - the whole political community - had little or nothing to say about the fulfillment of the promises since they were mere "wards", speechless minors of age.

It is relevant to note the parallel political outcomes of the confronted worlds of Calvinist and Catholic resistance to monarchy. It is well known that The French Wars of Religion (1562-1598) show this point in a nutshell. The Huguenot argument for resistance by inferior magistrates against Charles IX was recycled into the Catholic-Leaguer claims to papal intervention and clerical independence against the crown under Henry III and Henry IV. But this was not just a matter of fiduciary argumentative structure or shared legal metaphors. They all had a well-documented fear of popular agency — an empirical phenomenon disregarded in their respective models of the divine trust, in which the people were just passive wards.

An early outline of Protestant resistance by lesser magistrates can be found in the Magdeburg Confession (1550), a Gnesio-Lutheran document which promoted the Second Schmalkaldic War (1552-1555) against the imperial-catholic leonine conditions set by the Augsburg Interim. It is more than a declaration of faith, for it situated Protestant resistance at the center of imperial affairs, giving us an invaluable insight of where the Magdeburg ministers placed themselves in the political conjuncture. Meaningfully, the "first" "detestable error" to cope with was not one committed by Pope, Princes or Emperor, but by those "Donatists and Ana- 
baptists" who "constitute their own assemblies" where they dare to "say that they are equally saints" (1550, D3v). Anabaptists "partly abolish laws" (1550, B3v) and, even more devilishly, they "deny that political and domestic [oeconomica] offices are legitimate among Christians, abolishing magistrates, courts, the property over things, contracts and so on" (1550, E1).

The plebeian claim in the words of Thomas Müntzer during the German Peasant's War (1524-1525) - "the great do everything in their power to keep the common people to perceiving the truth" (Cohn, 1970, 242) - that the very Luther had the chance to condemn proved to be only a noteworthy case of something much bigger and older, shaking the lowest layers of feudal life (Domènech, 1999). The spreading of a multifarious "Anabaptist" specter instilling the religious and political-economic demands of Europe's lowest peoples would always haunt 16th and 17th centuries Calvinist thought across Europe. The Huguenot politics of the Vindiciae can be situated accordingly in a wider nobiliary tradition of corporatist defense of privileges against the centralizing efforts of the French monarchy (Wood, 2012, 147-210) - thus inherently reluctant to popular agency, especially in a mostly Catholic country with multitudes prone to violence, as the Massacre of St. Bartholomew (1572) tragically showed.

On the contrary, Daniel Lee (2008) has seen in the Vindiciae contra tyrannos and in François Hotman's Francogallia (1573) a "populist" stance. Made possible by their use of Roman private-law institutions, their idea of government as a mere guardianship of the people's inalienable dominium would be a step toward full "popular sovereignty" - maybe a dangerous step even for 21st century politics, for it would unbridle the people from constitutional limits (Lee, 2008, 399). But asserting a "popular" or "democratic" sovereign - a completely cogent concept not only for medieval scholastics but also for "modern" absolutists as Hobbes and Bodin, as long as it remained "sleeping" (Tuck, 2015) - does not necessarily lead to popular or democratic rule. This point has been lately made by Lee himself, since he has consistently identified an early modern idea essential for this paper: an "interest-based, non-agential conception of peoplehood" (Lee, 2016, 304). However, his reading of the French monarchomachi remains unchanged, i.e. as builders of a Roman private-law frame for "popular resistance" (Lee 2016, 149-55; 2018).

Lee's own late normative remarks serve us to beg the question: what is the actual "popular" or "populist" share in the Monarchomach understanding of "popular sovereignty"? For instance, it seems that Hotman's assertion of the inalienable dominium of the people gets balanced in a rather anti-populist manner by his praise of mixed government and his corporatist ideas of representation (Hotman, 1972, 286ff). And considering the secular roman-law sources of these tracts ought not to move us away from their insistence on Pauline subjection. "If the nobles and magistrates applaud a raging king, or at least do not resist him, Christ's counsel is ready to hand": Private persons should flee to another city, but if this has "not been granted, they should renounce life rather than God, and be crucified themselves rather than crucify Christ anew, as the apostle says" (Brutus, 1994, 61). This religious language should not be set aside as mere biblical rhetoric, because it was ingrained in certain (secular) political processes and institutions.

The only two exceptions to collegiate or ephoral resistance in the Vindiciae are: (1) a private action of self-defense against a tyrant without title (Brutus, 1994, 150) - a more or less unproblematic case at least since Bartolus of Saxoferrato-; and (2) a leading resistant individual directly raised up by God (1994, 61-62). And this second case has a most telling caveat: 
But when God has neither spoken with his own mouth nor, extraordinarily, through the prophets, we should be especially sober and circumspect in this matter (...) people should also beware lest in desiring to be a soldier under Christ's ensign (...) as happened not long ago in Germany with the followers of Thomas Müntzer (1994, 62) [italics are mine].

Theodore Beza, the third Huguenot triumvir, is conveniently disregarded in Lee's interpretation. Beza, an utmost advocate of religious repression in Geneva and successor of Calvin himself, was responsible of excluding the congregationalist tendencies within French Calvinism led by Jean Morely, who was dangerously rendering egalitarian ecclesiological principles into democratic politics (Kingdon, 1964). And as the author of the Vindiciae did, Beza, of course, had those "enraged Anabaptists and other seditious and mutineers" in mind, who "deserve the hate of all other men", when he developed his influential tract supporting resistance only by lesser magistrates (Beza, 1574, 9). In short, despite the jurisdictional and corporatist chances of resistance, there was not a proper individual right to resist, for the "correction of unbridled despotism is the Lord's to avenge", it is not "entrusted to us" (Calvin, 1963, IV, 20, 31). This was the appropriate position to vindicate toleration and "constitutionalism" in the face of Pope, Emperor or kings, while justifying a repressive subjection in the face of the presbytery ${ }^{3}$.

\section{The people as God's trustees: Leveller democratic republicanism and natural law}

\section{I}

Jordi Mundó (2017) has noted a revealing view on the threefold fiduciary structure we are tracing - God (Principal), magistrate (Agent), community (Beneficiary) - in the early works of John Locke, in his Two Tracts of Civil Government written in the 1660's:

Not that I intend to meddle with that question whether the magistrate's crown drops down on his head immediately from heaven or be placed there by the hands of his subjects (Locke, 1967, 174-175).

In the thread we are following, all parties made it clear that a community subject to political authority is the beneficiary of a trust-like settlement, whose original primary trustor could not be other than the first efficient cause of everything: God. Then, one of the issues

3 Althusius' Politica (1603) followed almost literally the Vindiciae in mapping government as a Roman tutela (Althusius 1995, ch. 18, §10-12). But against standard Calvinist lesser magistracy, Althusius accepted a very exceptional case of resistance by private persons: they were "armed" "by natural law" if the magistrate "lays violent hands upon them" (1995, ch. 38, §65-67). This exception suits well with his rather secular and nonsectarian views on limited religious toleration, in particular with the idea that persecution must never threaten the safety of the commonwealth by fostering civil conflicts (1995, ch. 23, §65). Emden, where Althusius held public office until his dead, turned into a religious haven for Reformed refugees during the second half of the 16th century, including a well-settled Anabaptist-Mennonite community (Fehler, 2018). Emden's orthodox Calvinists, threatened by Habsburg Catholicism and an intolerant Lutheran provincial nobility, had to coexist relatively peacefully with Anabaptism, introducing an important tolerationist core to the Dutch Second Reformation - a context, in conclusion, very different from the contemporaneous repressive politics of Geneva. 
at stake was precisely who trusted the authority to the prince: if God immediately or mediately through other agents. Although Locke seemed not to care about the answer - since he favored unrestrained monarchy by the time $(1967,126)$ - "to meddle with that question" entailed unburying debates that have had revolutionary consequences only less than twenty years before this passage was written.

Many of the early 17th century English "gathered churches" - the reformed religious base of the Levellers and the file-and-rank of the parliamentary "New Model Army" during the English Civil Wars (1642-1651) - were already quite far from Calvinist orthodoxy. Some were indeed very close to those Anabaptist "errors" that haunted the continental supporters of magisterial resistance, sometimes even arriving to antinomian conclusions (Wootton, 1991), progressively separating these groups from the moderate and conservative views represented in Parliament. These "lower-class heresies" (Hill, 1972, 21ff) carried a centuries-old materialism and anti-clericalism, and theological views able to justify their immediate political-economic interests. They were dangerous in a country where, as its monarch thought in 1646, "people are governed by the pulpits more than sword in times of peace" (Brailsford, 1961, 26). The growing number of so-called "mechanical preachers" wage-earner lay priests, elected and sometimes funded by their own congregations - easily threatened the theological foundations of secular government. This ferment finally boiled over thanks to the Habeas Corpus Act of 1640, which broke down the Star Chamber, greatly diminishing royal censorship and religious persecution during the next decades.

Many champions of the Parliament's cause against Charles I's personal rule framed their claims in terms of a revocable trust. For Henry Parker "all rule is but fiduciarie" $(1642,20)$. The king was the wielder of the nation's interests represented in Parliament, which had the "absolute indisputable power of declaring Law". This exalted attack to monarchical absolutism included an uncertain glimpse of popular sovereignty within it, since Parliaments were "to be accounted by the vertue of representation, as the whole body of the State" (Parker, $1642,45)$. The idea that Parliament represented the people against king opened a gap of premonitory inconsistencies rapidly exploited by royalist propaganda (Wootton, 1986, 47-48). If all rule is but fiduciary of the whole people's interests and originated by that people's trust, was not Parliament also exposed to be dissolved by the people at bene placitum?

Regardless of the alarming logical implications of some arguments, the royalist fear of parliamentarian appeals to the people was not only provoked by political pamphlets. The "Root and Branch Petition" of 1640 showed how popular discontent could be rallied against the Laudian Anglican Church - too theologically and ritually dependent on Catholicism, rigidly Episcopalian, intolerant and friend of royal prerogative. The impeachment against the Earl of Strafford during the next year mobilized the London multitude too. The multitude was again agitated by John Pym in the Grand Remonstrance during that winter. This atmosphere between 1640 and 1642 of constant petitioning to the Long Parliament along with insolent multitudes expanding the public sphere has been qualified as a "revolution within the revolution" (Cressy 2003).

The agency of the "multitude" or "people" was not just an analytically problematic theoretical concept, neither a mere intellectual byproduct of parliamentary pamphleteering or royalist critique. The people outside parliament were that fearsome empirical phenomenon whose agency had been systematically disregarded by political theory, but that nevertheless 
stubbornly determined it (Wood, 2012, 220ff). In a later response to royalist accusations of populism, Henry Parker's influential defense of parliamentary sovereignty asserted that "Parliament" - that middleman between Crown and the people's trust - "is indeed nothing else, but the very people it self artificially congregated, or reduced by an orderly election, and representation" (Parker, 1644, 18). And to calm demophobic moods he added that Parliament "can have no interests different from the people represented, or at least very few, and those not considerable" (Parker, 1644, 19) - something which only a few years later was proven to be evidently false.

\section{II}

Once the royalist army was defeated in Naseby in July 1645 and the king was captured, the institutionally hegemonic conservative and moderate factions of the parliamentary side started to negotiate a constitutional settlement with Charles I. However, on June 1647 the file-and-rank of a politically and religiously radicalized parliamentarian army stepped forward against their commanders' lack of political initiative and seized the king from Parliament's custody. In November, representatives chosen by the regiments and commanding officers of the Army gathered at Putney to discuss their respective demands regarding the afterwar institutional arrangements.

The Putney Debates revealed a political gap that in some way had been anticipated by royalist thinkers during the early 1640's before the outbreak of the war. In spite of Henry Parker, Parliament was not the same as people. The Presbyterian-dominated Long Parliament was not only being too generous in its peace negotiations with Charles but, more importantly to the civilian and Army radicals, it was trying to impose a Presbyterian national church on the Scottish model (as addicted to censorship and civil power, as intolerant and almost as hierarchical as the loathed pre-war Anglican establishment). Consequently, the relationship between the state and the people outside parliament was among the key issues debated by the Army at Putney in 1647.

The fiduciary conception of authority was not only articulated by the royalist side - as the God's commission to the king - or by the champions of parliamentary sovereignty — as the Parliament's trust upon the king - but also by the non-royalist critics of Parliament. When Charles I was reaching a secret military agreement with the Scots (definitively turning the Presbyterian faction against the Army) and precipitating the second civil war, Army supporters also justified the 1648 purge of the Long Parliament in terms of failed fiduciary duties.

Presbyterian and moderate MPs against the Army's purposes to put Charles on trial almost half of the total seats - were imprisoned or deposed from office during mid-December by a regiment led by Thomas Pride, presumably under Cromwell's orders. The Arminian preacher John Goodwin defended the Army's maneuvers against the Long Parliament in his Might and Right Well Met (1649), cleverly using previous arguments held against Charles by now-imprisoned Presbyterians. The king had been considered by them like "the pilot or master of a ship" who, if "distempered with drink or otherwise disabled" and "incapable of acting the exigencies of his place for the preservation of the ship", can and should be deposed "by inferior mariners". These lesser officers "may lawfully assume, and act according to, the interest of a pilot or master" (Woodhouse, 1992, 214).

John Goodwin radicalized and set an extra-institutional element to this old Calvinist argument of resistance by inferior magistrates, framing the Army's coup d'état against the 
Long Parliament also as the claim that inferior sailors have against their captain's breach of duty ${ }^{4}$. By doing that, Goodwin wanted to counter the idea according to which Parliament could depose the monarch in the same way as a "client" might do with his "advocate", but the Army, on the other hand, could never do the same with Parliament, because that would be as if a "pupil" discharged "his guardian" (Woodhouse, 1992, 215). (It was a rather revealing objection, invoking a core principle of fiduciary government).

Goodwin's argument could not end there. He had justified the Army's agency against the breach of trust of king and also against "the miscarriages of Parliament". However, under the same logic, could not the people outside Parliament hold the Army accountable should it act against the national interests? It was a plausible question, given that the Levellers had been nourishing democratic sentiments in the City and in other parts of England, with a worrying presence among several Army regiments. They were just waiting for the new war to finish in order to go over the many unsettled points debated at Putney.

In an incredible case of fiduciary juggling, Goodwin denied any popular agency against Army and/or Parliament. To the objection that his argument may lead to populist anarchy, he noted "that physicians, called to the care and cure of persons under distempers, need not much stand upon the consents of such patients (...) about what they administer unto them". And people outside Parliament were "incapable in themselves of the things of their peace". As "it is a deed of charity and Christianity, to save the life of a lunatic or distracted person even against his will", Army's unilateral actions had been "God's providence" (Woodhouse, 1992, 216)5.

The political value of Goodwin's pamphlet consists in that he was able to embed the growing political autonomy of the New Model Army in a Calvinistic fiduciary argument accepted by most parliamentarians, whilst excluding the Leveller democratic demands against Parliament and within the Army itself. Those demands were very present by the time of Pride's Purge (December 1648). Only a year before, John Wildman - a Leveller civilian speaking at Putney - had noted that the relationship between people and political institutions was much more than a matter of "will"; that even a voluntary concession of power with servile consequences (as to a despotic Parliament) could not be considered just. Those agreements in fact should be resisted, since the New Model Army "stood upon such principles of right and freedom, and the Laws of Nature and Nations, whereby men were to preserve themselves though the persons to whom authority belonged should fail in it" (Woodhouse, 1992, 24).

Wildman's attacks against any unjust political subjection were totally cogent with the fiduciary understanding of political power that other civilian Levellers had fully developed already by the mid-1640s against the Long Parliament. Elizabeth Lilburne petitioned to the "betrusted" members of the High Court of Parliament, referring to "the duty you owe to the Kingdome

4 The fiduciary metaphor of the uncapable shipmaster can be found, practically verbatim and with a corporatist bent, in the Vindiciae contra tyranos (Brutus, 1994, 75, 164, 168). The Marian exile John Ponet, another 16th century source for English puritans, used it in a more radical sense, not necessarily attached to magisterial resistance (Ponet, 1970, Gv).

5 This was not new either. Jointly with guardianship (see e.g. Cicero, 1991, I, 85; I, 124), framing government as piloting a ship or practicing medicine were probably among the most common metaphors to make sense of the fiduciary nature of public office. The original classical use of these two metaphors was unmistakably antidemocratic. Cicero in his De re publica makes Scipio speak of the several skills needed by the helmsman of a ship to rule out the epistemic egalitarianism implied by democracy in contrast to aristocracy (1999, bk. I, 51, 62; bk. V, 5). In Plato's Republic the example of the physician serves to justify a magistrate lying to his subjects $(1986,389 \mathrm{~b})$. 
according to the GREAT TRUST reposed in you" (Lilburne, 1646). Overton and Walwyn thought that a seat in the House of Commons was itself an office upon trust, as conditional and revocable as the superior magistracy: "we possessed you with the same power that was in ourselves to have done the same" and "this was only of us but a power of trust - which is ever revocable, and cannot be otherwise - and to be employed to no other end than our own wellbeing". In short: "We are your principals, and you our agents". Failing that trust was "inconsistent with the nature of just freedom, which ye also very well understand" (Sharp, 1998, 33-34)6.

But how can one justify that, even if someone wants to alienate his or her liberty to a tyrant, the result of such agreement could not be considered just and must therefore be resisted? Which was the source of those "Laws of Nature" that restrain what community and individuals can do with their sovereignty? From a Leveller point of view, why was Henry Ireton wrong, in terms of public law and "just freedom", when he contended at Putney against the radicals that "volenti non fit injura"? These questions were rhetorical for any diligent reader of the Bible, since they already knew that every human power was originally endowed by God.

\section{III}

Samuel Rutherford completely perceived the ambivalent role of trust in the political theory of his age:

That the power of the king is fiduciary, that is, given to him immediately by God in trust, royalists deny not; but we [parliamentarians] hold that the trust is put upon the king by the people (Rutherford, 1644, 124).

But as we have seen, many other institutions different than the people themselves may act to check their fiduciaries. For a Presbyterian like Rutherford there was also some chance of corporatist resistance to representative institutions $(1644,152)$. But by contrast to the Levellers, he was still trapped in his Calvinistic obsession with human sin. Although the institution of one government or another may be a human decision, the fact of government is divinely ordained and cannot be resisted privately, least of all appealing to prelapsarian natural law and freedom - and in this he stood firmly upon a certain familiar tradition: that of "Beza, Calvin, Luther, Bucer" against "Anabaptists and Libertines, who in that time maintained, that we are all free men in Christ" (Rutherford, 1644, 273). A political tradition suitable for his absolutistic and intolerant project of a Presbyterian national church.

Even before their final alliance with Charles I in 1648, Presbyterians on the parliamentary side were considered by the Levellers as despotic as royalists. Both factions were as bad as "papists", for all of them approved some kind of authority by iure divino - i.e. immediately committed by God and therefore not accountable to the people. By the 1650s the same critique was applied to the Army's command and Cromwell's Protectorate. Walwyn made

6 Among many other examples, see also this idea in John Lilburne (Wolfe, 1944, 14; Sharp, 1998, 5) or Overton (Wolfe, 1944, 162).

7 A common-law principle according to which there is no injustice in an agreement if the parties acted willingly. Ireton, as Pride's purge showed the next year, was willing to break this principle between Parliament and king or Army and Parliament, but never between people and Parliament. The same idea sat well with Theodore Beza's magisterial resistance $(1574,21)$. 
it very clear: "they are but corrupt and dangerous flatterers [those] that maintaine any such fond opinions concerning either Kings or Parliaments" (Haller, 1965, 316) ${ }^{8}$.

Ideologically fighting all of their political foes at the same time, the Levellers asserted popular sovereignty by remaking a millenary divine trust. As John Lilburne liked to say, paraphrasing the failed promise of the Rump Parliament: "the people (under God) are the original of all just powers" (Sharp, 1998, 140). The Leveller conception of fiduciary government operates as a second-order fiduciary relationship restrained by the primeval divine commission:

we the free people of England, to whom God hath given hearts, means and opportunity to effect the same, do with submission to His wisdom, in His name, and desiring the equity thereof may be to His praise and glory, agree to ascertain our government, to abolish all arbitrary power and to set bounds and limits both to our supreme and all subordinate authority, and remove all known grievances (Sharp, 1998, 170) ${ }^{9}$.

It was also Richard Overton's idea in An arrow against all tyrants. From the law of nature "all just human powers take their original — not immediately from God (as kings usually plead their prerogative) but mediately by the hand of nature, as from the represented to the representers". These powers were "implanted" by God "in the creature", and "no second may partake but by deputation, commission, and free consent from him whose natural right and freedom it is". Any consent to authority must be "for the better being, weal, or safety". "He that gives more, sins against his own flesh; and he that takes more is thief and robber to his kind" (Sharp, 1998, 55-56).

Unlike young John Locke, the Levellers had the courage "to meddle" with a fundamental issue at stake: the role of the people as more than passive beneficiaries. Leveller political theology placed a politically capable humanity as the immediate trustees of God, whose normative expectations were implanted in the law of nature - universal, non-waivable and imprescriptible boundaries to public and private power. Despite contemporary suspicions regarding strong democracy as a right-eroding tradition, it was a movement fostering a strong extrainstitutional popular agency which brought that old tradition of "rights" to modern politics.

\section{Conclusion}

It has been argued that behind the basic normative expectations of modern fiduciary law lies a moral architecture of "mandatory rules". The so-called "mandatory core" insulates fiduciary obligations that the law assumes would not be bargained away by a fully informed, sophisticated principal. True, in an individual case a particular principal might be fully informed and have good reason to want to bargain away something from the mandatory core. But such circumstances are infrequent enough that a prophylactic (if paternalistic) mandatory rule may be justified nonetheless (Stikoff, 2016, 205).

8 See also Sharp $(1998,10,45)$

9 Note that the ostensibly oxymoronic idea of "our supreme and all subordinate authority" makes complete sense in this fiduciary relational structure: the people is trusting something - their liberty - which was previously entrusted to them by God. Another clear exposition of the idea is in his postscript to The freeman's freedom vindicated (Sharp, 1998, 31). 
These rules "cannot be overridden by agreement", for they "serve an internal protective and cautionary function that protects the principal" - in other words, that parties in a fiduciary relationship "do not have complete freedom of contract" (Stikoff, 2016, 204-205). These rules can be explained in terms of republican freedom understood as non-domination (Criddle, 2019, 1049ff). The "mandatory core" protects individuals against any potential arbitrary interference in their liberty, setting mechanisms that safeguard them even against their own will. Note that asserting the fiduciary nature of government affects much more than public law or the relationship between individuals and state. It also structures our understanding of private law and private relationships in a rule-of-law state. Every relationship among private persons ought to respect this indefeasible core in order to be recognized as legal - any other agreement against what would be bargained by a hypothetical fully rational and informed individual must be null and void. A fiduciary understanding of government implies, in essence, a substantive, non-instrumental idea of humanity, perfectly epitomized in legal-philosophical terms by Kant: "someone can be his own master (sui iuiris) but cannot be the owner of himself (sui dominus) (cannot dispose of himself as he pleases - still less can he dispose of other as he pleasessince he is accountable to the humanity in his own person)" (quoted by Bertomeu, 2017, 497).

In the mind of the Levellers these restrains were still theologically justified by an original divine trust. Humans could not be sui dominus, since they held their "self-propriety" as mere trustees of God, who endowed it for reasons that exclude subjection to any arbitrary power public or private. The Leveller theological position, however, had the seed of secularization. For Walwyn, the divine trust was expressed "by the hand of nature" and God had expressed himself "so plainly, that the meanest capacity is fully capable of a right understanding thereof". The democratic conclusion came quickly: "[L]et every one freely speake his minde without molestation: and so there may be hope that truth may come to light" (quoted by Morton, 1970, 149).

For them - and this was the crucial difference against their rivals - the purposes of the godly trust (the fulfillment of human life) were not encrypted anymore. There was no need for unaccountable intermediate agents to decipher its conditions: neither presbyter, pope, king or lesser magistrate. Trustworthy institutions to achieve human freedom must be accountable to those subject to them, who are not minors of age. Although politically defeated, the democratic-republican wing of the English Revolution won an important intellectual battle, whose achievements still resound in Eugène Pottier's lyrics of L'internationale: "Il n'est pas de sauveurs suprêmes/Ni Dieu, ni César, ni tribun/Producteurs, sauvons-nous nous-mêmes/ Décrétons le salut commun".

\section{Bibliography}

Althusius, J. (1995), Politica methodice digesta, edited by F. S. Carney, Indianapolis: Liberty Fund.

Bellarmine, R. (2012), On Temporal and Spiritual Authority, edited by Stefania Tutino, Indianapolis: Liberty Fund.

Bertomeu, M. J. (2017), "Pobreza y propiedad. ¿Cara y cruz de la misma moneda? Una lectura desde el republicanismo kantiano", Isegoría, 57, pp. 477-504.

Beza, T. (1574), Du droit des magistrats sur leurs subiets, Magdeburg. 
Bossuet, J. B. (1990), Politics Drawn From the Very Words of Holy Scripture, edited by Riley, Cambridge: CUP.

Brailsford, H. N. (1961), The Levellers and the English Revolution, edited by C. Hill, London: The Cresset Press.

Brutus, S. J. (1994), Vindiciae contra tyrannos, edited by G. Garnett. Cambridge: CUP.

Calvin, J. (1963), Institutes of the Christian Religion, trans. F. L. Battles, edited by J. T. McNeill, Louisville: The Westminster Press.

Cicero, M. T. (1991), On Duties, edited by M. T. Griffin, trans. E. M. Atkins, Cambridge: CUP.

Cicero, M. T. (1999), On the Commonwealth and On the Laws, edited and trans. by J. Zetzel, Cambridge: CUP.

Cohn, N. (1970), The Pursuit of the Millennium, Oxford: OUP.

Cressy, D. (2003), “Revolutionary England 1640-1642”, Past \& Present, 181(1), pp. 35-71.

Criddle, E. J., Fox-Decent, E., Gold, A. S., Kim, S. H. and Miller, B. (eds.) (2018), Fiduciary Government, Cambridge: CUP.

Criddle, E. J. (2017), "Liberty in Loyalty: A Republican Theory of Fiduciary Law", Texas Law Review, 95, pp. 993-1060.

Domènech, A. (1999), "Cristianismo y libertad republicana: Un poco de historia sacra y un poco de historia profana”, La Balsa de la Medusa, 51-52, pp. 3-47.

Fehler, T. (2018), “Coexistence and Confessionalization. Emden's Topography of Religious Pluralism", in: Plummer, M. E. and Christman, V. (eds.), Topographies of Tolerance and Intolerance, Leiden: Brill, pp. 78-105.

Figgis, J. N. (1922), The Divine Right of Kings, Cambridge: CUP.

Fox-Decent, E. (2012), Sovereignty's Promise: The State as Fiduciary, New York: OUP.

Gierke, O. von (1900), Political Theories of the Middle Age, trans. F. W. Maitland, Cambridge: CUP.

Haller, W. (ed.) (1965), Tracts on Liberty in the Puritan Revolution, 1638-1647, vol. III, New York: Octagon Books.

Hill, C. (1972), The World Turned Upside Down, London: Maurice Temple Smith.

Hotman, F. (1972), Francogallia, trans. J. H. M. Salmon, edited by R. Gisey, Cambridge: CUP.

James I King of England (1994), Political Writings, edited by J. Sommerville, Cambridge: CUP.

Kingdon, R. (1964), "Calvinism and Democracy: Some Political Implications of Debates on French Reformed Church Government, 1562-1572", The American Historical Review, 69(2), pp. 393-401.

L'Estrange, R. (1678), Two cases submitted to consideration, London: Randal Taylor.

Lee, D. (2008), "Private Law Models for Public Law concepts", Review of Politics, 70(3), pp. 370-399.

Lee, D. (2016), Popular Sovereignty in Early Modern Constitutional Thought, Oxford: OUP.

Lee, D. (2018), “The State Is a Minor”, in: Criddle et al. (eds.), Fiduciary Government, Cambridge: CUP, pp. 119-145.

Lilburne, E. (1646), To the chosen and betrusted knights, citizens..., London: s. n.

Locke, J. (1967), Two Tracts on Government, edited by P. Abrams, Cambridge: CUP. 
Magdeburg ministers (1550), Confessio et apologia pastorum \& reliquorum ministrorum Ecclesiae Magdeburgensis, Magdeburg: s. n.

Maloy, J. S. (2008), The Colonial American Origins of Modern Democratic Thought, Cambridge: CUP.

Miller, B. and Gold, A. S. (2015), "Fiduciary Governance", William \& Mary Law Review, 57(2), pp. 513-586.

Morton, A. L. (1970), The World of the Ranters, London: Lawrence and Wishart.

Mundó, J. (2017), "La constitución fiduciaria de la libertad política. (Por qué son importantes las coyunturas interpretativas en la filosofía política)", Isegoría, 57, pp. 433-454.

Parker, H. (1642), Observations upon some of His Majesties late answers and expresses, London: s. n.

Parker, H. (1644), Jus populi, London: Robert Bostock.

Pettit, (1997), Republicanism, Oxford: OUP.

Plato (1986), The Republic, trans. Allan Bloom, Harper Collins.

Ponet, J. (1970), A short treatise of politic power (facsimile of 1556), Menston: Scolar Press.

Rutherford, S. (1644), Lex Rex, London: John Field.

Sharp, A. (ed.) (1998), The English Levellers: Political Writings, Cambridge: CUP.

Skinner, Q. (1978), The Foundations of Modern Political Thought, vol 2: The Age of Reformation, Cambridge: CUP.

Stikoff, R. H. (2016), “An Economic Theory of Fiduciary Law”, in: Gold, A. S. and Miller, B. (eds.), Philosophical Foundations of Fiduciary Law, Oxford: OUP, pp. 197-208.

Suárez, F. (1944a), De legibus, in: Williams, G.L. (ed.), Selections From Three Works of Francisco Suarez, vol. 2, Oxford: Clarendon, pp. 3-646.

Suárez, F. (1944b), Defensio fidei catolicae, in: Williams, G.L. (ed.), Selections From Three Works of Francisco Suarez, vol. 2, Oxford: Clarendon, pp. 647-725.

Tierney, B. (1982), Religion, Law, and the Growth of Constitutional Thought, 1150-1650, Cambridge: CUP.

Tierney, B. (2001), The Idea of Natural Rights, Grand Rapids: Eedermans.

Tuck, R. (2015), The Sleeping Sovereign, Cambridge: CUP.

Ullmann, W. (2010), Principles of Government and Politics in the Middle Age, Oxon: Routledge.

Wolfe, D. M. (ed.) (1944), Leveller Manifestoes of the Puritan Revolution, New York: T. Nelson and Sons.

Wood, E. M. (2012), Liberty and Property, London: Verso.

Woodhouse, A. S. (ed.) (1992), Puritanism and Liberty, 3rd ed., New York: Dent.

Wootton, D. (1986), Divine Right and Democracy, Suffolk: Penguin Books.

Wootton, D. (1991), "Leveller Democracy and the Puritan Revolution", in: Burns, J. H. and Goldie, M. (eds.), The Cambridge History of Political Thought, 1450-1700, Cambridge: CUP, pp. 412-442. 